\title{
Correlation and Path Coefficient Analysis for Seed Cotton Yield and its Components in Desi Cotton (Gossypium arboreum L.)
}

\author{
A. D. Mankar, D. B. Deosarkar and V. N. Chinchane* \\ Department of Agricultural Botany, Genetics and Plant Breeding, Vasantrao Naik \\ Marathawada Krishi Vidyapeeth, Parbhani. 431402 (M.S.), India \\ *Corresponding author
}

Keywords

Correlation, Direct effect, Path analysis, Genotypic

Article Info

Accepted:

17 January 2021

Available Online:

10 February 2021

\section{A B S T R A C T}

In the present investigation, 39 desi (Gossypium arboreum L.) genotypes along with three checks viz., AKA-7, PA-08 and JLA-794 were studied to observe correlation and path analysis for fifteen yield contributing and fibre quality characters. Analysis of variance showed significant differences for all the characters among genotypes indicating the presence of wide range of genetic variability in the experimental materials. The correlation studies revealed positive and significant genotypic and Phenotypic correlation of days to $50 \%$ flowering and upper half mean length with seed cotton yield per plant. The path coefficient analysis revealed that, the traits viz., days to $50 \%$ flowering, days to $50 \%$ boll bursting, plant height, number of sympodia per plant, number of bolls per plant, boll weight, seed index, ginning percent, fiber strength and uniformity ratio exerted direct positive effect on seed cotton yield. Therefore, these characters should be given due emphasis for making selection for high yielding genotypes in desi cotton.

\section{Introduction}

Cotton is being cultivated in 70 countries of the world with a total coverage of $33.14 \mathrm{~m}$ ha. China, India, USA and Pakistan are the major cotton producing countries in the world accounting for 70 per cent of the world's cotton area and production. India is the largest cotton growing country in the world with
35.29 per cent of world cotton area followed by China $(15.23 \%)$. China and India are the major cotton consuming countries in the world (around 55\%). USA and India constitute 27 and 19.5 per cent of the worlds cotton exports respectively. Out of four cultivated species of genus Gossypium, only two species i,e. $G$. hirsutum and G.arboreum are being mostly cultivated in Maharashtra. In the last few years 
there has been a significant reduction in the area of G. arboreum cotton across the country and particularly in Maharashtra because of lower productivity and inferior fiber properties as compare to tetraploid cotton in rainfed ecosystem. Therefore, more emphasis should be given to increase the seed cotton yield per unit area of desi cotton, by developing varieties with short stature, big boll size and medium to longer staple length with sustained yield in multiple environments. To achieve such desirable characteristics in new variety, proper breeding strategies should be followed.

In plant breeding, correlation coefficient analysis measures the mutual relationship between various plant characters and determines the component characters on which selection can be based for genetic improvement in yield. Direction and magnitude of correlation between yield and yield contributing characters must be considered for selection of superior genotypes from diverse genetic population but correlation does not provide information about direct and indirect effects of independent variable on dependent one, for this path coefficient analysis is essential. Path analysis splits correlation coefficient into the measures of direct and indirect effects, which reveals whether the association of these characters with yield is due to their effects on yield or is consequence of their indirect effect via other component characters. Thus, it measures cause of association between two variables and effect situation.

\section{Materials and Methods}

The experiment was carried out during kharif, 2018 at Cotton Research Station, Mahboob Baugh Farm, Vasantrao Naik Marathwada Krishi Vidyapeeth, Parbhani. The experimental material consisted of 42 diverse elite genotypes of desi cotton (Gossypium arboreum L.) including three checks viz.,
AKA 7, PA 08 and JLA 794. The experimental material was sown by dibbling 2-3 seeds / hill. Recommended agronomical and plant protection practices were followed regularly. Fertilizer dose of 50:25:25 kg NPK/ha was applied to the crop, out of which 25:25:25 $\mathrm{kg} \mathrm{NPK} / \mathrm{ha}$ was given at the time of sowing and remaining $25 \mathrm{~kg} \mathrm{~N} / \mathrm{ha}$ was applied 45 days after sowing. Observations were recorded on ten yield and yield contributing characters viz., days to 50 per cent flowering, days to 50 per cent boll bursting, plant height, sympodia / plant, bolls / plant, boll weight, seed index, lint index, harvest index and seed cotton yield / plant, five fibre quality characters viz., ginning per cent, upper half mean length, fibre strength, micronaire and uniformity ratio. In order to study the extent of association between different traits, the genotypic and phenotypic simple correlation coefficients were worked out from the respective variances and co-variances. The formulae as suggested by Johnson et al., (1955) were used for calculating simple correlation coefficients. The genotypic correlation coefficients between yield and its components were further partitioned into direct and indirect effects with the help of path coefficient analysis given by Dewey and Lu (1959).

\section{Results and Discussion}

The correlation studies were undertaken in 42 genotypes, in order to find out interrelationship of different yield components at genotypic and phenotypic levels. The genotypic $(\mathrm{G})$ and phenotypic $(\mathrm{P})$ correlation coefficients for 15 characters is presented in Table 1 and 2 respectively. Number of bolls per plant exhibited positive correlation with seed index at genotypic and phenotypic level. Positive non-significant correlation were observed with harvest index, micronaire, boll weight, seed cotton yield per plant, upper half mean length, and uniformity ratio. It had 
negative and non-significant correlation with lint index, ginning percent and fiber strength at both genotypic and phenotypic level. Days to 50 percent flowering had positive and significant correlation with number of bolls per plant, uniformity index and harvest index at both genotypic and phenotypic level. Number of sympodia per plant exhibited negative and significant correlation with uniformity ratio at both genotypic and phenotypic level.

It had showed positive and weak correlation with boll weight, number of bolls per plant, seed cotton yield per plant and micronaire at both genotypic and phenotypic level while, negative non-significant correlation were observed with fiber strength, uniformity ratio, upper half mean length, ginning percent, lint index, seed index and harvest index.

The character harvest index exhibited positive and significant correlation with days to $50 \%$ flowering at both the level of correlation. Weak positive correlation was observed with number of bolls per plant, plant height, boll weight, fiber strength and seed cotton yield per plant at both the level of correlation. The character ginning percent exhibited significant correlation with upper half mean length at both genotypic and phenotypic level. Positive and non-significant correlation with lint index, micronaire and seed cotton yield per plant at genotypic and phenotypic level while, negative and nonsignificant correlation with uniformity ratio, fiber strength and seed index were observed at both the level of correlation. Upper half mean length exhibited positive and significant correlation with fiber strength at both genotypic and phenotypic level while negative and significant correlation with ginning percent, boll weight and micronaire were observed. The character fiber strength exhibited positive and significant correlation with upper half mean length at both genotypic and phenotypic level and negative and significant correlation with micronaire and boll weight at both the level of correlation.

Path analysis between yield, yield contributing and fibre quality characters were carried out to find the direct and indirect effect from given component characters on seed cotton yield. Path coefficient analysis was worked out for fifteen different characters at genotypic level only. The results are presented in Table 3. The character number of bolls per plant has positive direct effect $(0.9765)$ on yield. While, positive indirect effect via., boll weight (0.2732), days to $50 \%$ flowering (0.2315), number of sympodia per plant (0.1997), micronaire (0.1992) and harvest index (0.1164). Negative indirect effect was noticed through ginning percent ($0.107)$, plant height $(-0.0228)$, seed index ($0.3233)$. fibre strength $(0.0339)$ and lint index (0.0981). The results of path coefficient analysis revealed that days to 50 percent flowering has positive direct effect (0.257) on yield. It has positive indirect effect on yield through harvest index (0.120), uniformity ratio $(0.104)$ and number of bolls per plant (0.061).

Number of sympodia exhibited positive direct effect (0.0732) on seed cotton yield and positive indirect effect via., days to 50 per cent flowering (0.0055), number of bolls per plant (0.0150), boll weight (0.0130) and micronaire (0.0219). The character ginning percent had positive direct effect $(0.1454)$ on seed cotton yield and negative indirect effect via., days to $50 \%$ boll bursting (-0.0773), plant height (-0.0743), days to $50 \%$ flowering (-0.0605), fiber strength $(-0.0297)$, upper half mean length $(-0.0347)$, uniformity index (-0.0345) and seed index (-0.0077) while, Positive indirect effect via., lint index (0.0180), micronaire (0.0225), boll weight (0.0464) and harvest index (0.0180). 
Table.1 Genotypic correlation between yield and its components in cotton

\begin{tabular}{|c|c|c|c|c|c|c|c|c|c|}
\hline $\begin{array}{l}\text { Sr. } \\
\text { No. }\end{array}$ & Characters & $\begin{array}{c}\text { Days to } \\
50 \% \\
\text { flowering }\end{array}$ & $\begin{array}{c}\text { Days to } \\
\mathbf{5 0 \%} \\
\text { boll } \\
\text { bursting }\end{array}$ & $\begin{array}{c}\text { Plant } \\
\text { Height } \\
\text { (cm) }\end{array}$ & $\begin{array}{c}\text { Number } \\
\text { of } \\
\text { sympodia } \\
\text { per plant }\end{array}$ & $\begin{array}{c}\text { Number } \\
\text { of bolls } \\
\text { per } \\
\text { plant }\end{array}$ & $\begin{array}{c}\text { Boll } \\
\text { Weight } \\
\text { (cm) }\end{array}$ & $\begin{array}{c}\text { Ginning } \\
\text { percent } \\
(\%)\end{array}$ & $\begin{array}{c}\text { Lint index } \\
\text { (g) }\end{array}$ \\
\hline 1 & Days to $50 \%$ flowering & 1 & 0.1683 & 0.2270 & 0.0756 & $0.2371 *$ & -0.1117 & - & $-0.2644 *$ \\
\hline 2 & Days to $50 \%$ boll bursting & & 1 & 0.2741 & -0.2370 & -0.0059 & -0.2935 & $\begin{array}{c}- \\
05215 *\end{array}$ & $-0.3842 * *$ \\
\hline 4 & No. of sympodia per plant & & & & 1 & 0.2045 & 0.1781 & -0.0225 & -0.0565 \\
\hline 5 & No. of bolls per plant & & & & & 1 & 0.2798 & -0.0109 & -0.1004 \\
\hline 6 & Boll Weight (g) & & & & & & 1 & 0.3192 & 0.3814 \\
\hline 7 & Ginning percent $(\mathrm{g})$ & & & & & & & 1 & 0.1236 \\
\hline
\end{tabular}


Table.1 Conti....

\begin{tabular}{|c|c|c|c|c|c|c|c|c|}
\hline $\begin{array}{l}\text { Sr. } \\
\text { No. }\end{array}$ & Characters & $\underset{(\mathrm{g})}{\text { Seed Index }}$ & $\begin{array}{c}\text { Harvest } \\
\text { Index }\end{array}$ & $\begin{array}{l}\text { Upper } \\
\text { Half Mean } \\
\text { Length } \\
(\mathbf{m m})\end{array}$ & $\begin{array}{c}\text { Uniformity } \\
\text { Ratio }\end{array}$ & $\begin{array}{c}\text { Fiber } \\
\text { Strength } \\
\text { ( g/tex) }\end{array}$ & $\begin{array}{c}\text { Micronaire } \\
\text { (ug/inch) }\end{array}$ & $\begin{array}{c}\text { Seed cotton } \\
\text { yield per } \\
\text { plant }(\mathrm{g})\end{array}$ \\
\hline & & 9 & 10 & 11 & 12 & 13 & 14 & 15 \\
\hline 1 & Days to $50 \%$ flowering & $-0.3589 * *$ & $0.4683 * *$ & 0.1086 & $0.4050^{* *}$ & 0.0312 & 0.0264 & 0.2231 \\
\hline 2 & Days to $50 \%$ boll bursting & -0.2197 & -0.0034 & 0.1574 & 0.1835 & 0.0147 & 0.0591 & -0.0874 \\
\hline 3 & Plant height $(\mathrm{cm})$ & -0.0460 & 0.2210 & 0.0391 & 0.0149 & -0.0653 & -0.0984 & -0.0332 \\
\hline 4 & No. of sympodia per plant & -0.0504 & -0.0944 & -0.0146 & $-0.3210 * *$ & -0.1351 & 0.2994 & 0.2250 \\
\hline 5 & No. of bolls per plant & $-0.3310 * *$ & 0.1192 & 0.0234 & 0.0317 & -0.0347 & 0.1989 & 0.9876 \\
\hline 6 & Boll weight (g) & 0.1644 & 0.2691 & $-0.3697 * *$ & $-0.4553 * *$ & $-0.5030 * *$ & 0.3312 & 0.3626 \\
\hline 7 & Ginning percent $(\%)$ & -0.0528 & 0.0091 & $-0.2387^{*}$ & -0.2372 & -0.2043 & 0.1549 & 0.0665 \\
\hline 8 & Lint index (g) & $0.5404 * *$ & -0.0692 & -0.1532 & -0.0513 & -0.0341 & -0.1418 & -0.2789 \\
\hline 9 & Seed index (g) & 1 & 0.0828 & -0.3064 & -0.4770 & -0.3123 & 0.0657 & -0.4718 \\
\hline 10 & Harvest index & & 1 & -0.0001 & -0.01071 & 0.0632 & -0.2858 & 0.2781 \\
\hline 11 & Upper half mean length & & & 1 & 0.0673 & $0.4337 * *$ & $-0.6395 * *$ & -0.1139 \\
\hline 12 & Uniformity ratio & & & & 1 & 0.1297 & 0.0059 & -0.2289 \\
\hline 13 & Fiber strength (g/tex) & & & & & 1 & $-0.3271 * *$ & -0.1313 \\
\hline 14 & Micronaire (ug/inch) & & & & & & 1 & 0.1485 \\
\hline 15 & Seed cotton yield per & & & & & & & 1 \\
\hline
\end{tabular}

$*$ and $* *$ indicates significance at $5 \%$ and $1 \%$ level respectively 
Table.2 Phenotypic correlation between yield and its components in cotton

\begin{tabular}{|c|c|c|c|c|c|c|c|c|c|}
\hline $\begin{array}{l}\text { Sr. } \\
\text { No. }\end{array}$ & Characters & $\begin{array}{c}\text { Days to } \\
\mathbf{5 0 \%} \\
\text { flowering }\end{array}$ & $\begin{array}{l}\text { Days to } \\
\mathbf{5 0 \%} \text { boll } \\
\text { Bursting }\end{array}$ & $\begin{array}{c}\text { Plant } \\
\text { Height } \\
(\mathrm{cm})\end{array}$ & $\begin{array}{l}\text { Number of } \\
\text { sympodia } \\
\text { per plant }\end{array}$ & $\begin{array}{c}\text { Number of } \\
\text { bolls per } \\
\text { plant }\end{array}$ & $\begin{array}{c}\text { Boll weight } \\
\text { (g) }\end{array}$ & $\begin{array}{c}\text { Ginning } \\
\text { percent }(\%)\end{array}$ & $\begin{array}{c}\text { Lint index } \\
\text { (g) }\end{array}$ \\
\hline & & 1 & 2 & 3 & 4 & 5 & 6 & 7 & 8 \\
\hline 1 & Days to $50 \%$ flowering & 1 & 0.1728 & 0.2134 & 0.0856 & $0.2344 *$ & -0.0841 & $-0.2527 *$ & $-0.2362 *$ \\
\hline 2 & $\begin{array}{l}\text { Days to } 50 \% \text { boll } \\
\text { bursting }\end{array}$ & & 1 & 0.2021 & -0.1358 & -0.0113 & -0.0794 & $-0.3437 * *$ & $-0.2516^{*}$ \\
\hline 3 & Plant height (cm) & & & 1 & 0.0485 & -0.0598 & -0.0522 & $-0.3521 * *$ & -0.0839 \\
\hline 4 & No. of sympodia per plant & & & & 1 & 0.1265 & 0.1177 & 0.0184 & -0.0632 \\
\hline 5 & No. of bolls per plant & & & & & 1 & 0.1071 & -0.0474 & -0.0988 \\
\hline 6 & Boll weight (g) & & & & & & 1 & 0.2009 & 0.2021 \\
\hline 7 & Ginning percent $(\%)$ & & & & & & & 1 & 0.0920 \\
\hline 8 & Lint index $(\mathrm{g})$ & & & & & & & & 1 \\
\hline
\end{tabular}

$*$ and $* *$ indicates significance at $5 \%$ and $1 \%$ level respectively 
Table.2 Conti...

\begin{tabular}{|c|c|c|c|c|c|c|c|c|}
\hline $\begin{array}{l}\text { Sr. } \\
\text { No. }\end{array}$ & Characters & Seed index $(g)$ & $\begin{array}{l}\text { Harvest } \\
\text { Index }\end{array}$ & UHML(mm) & $\begin{array}{c}\text { Uniformity } \\
\text { Ratio }\end{array}$ & $\begin{array}{c}\text { Fiber strength } \\
(\mathrm{g} / \mathrm{tex})\end{array}$ & $\begin{array}{c}\text { Micronaire } \\
\text { (Ug/inch) }\end{array}$ & $\begin{array}{r}\text { Seed cotton } \\
\text { yield per } \\
\text { plant }(\mathrm{g})\end{array}$ \\
\hline & & 9 & 10 & 11 & 12 & 13 & 14 & 15 \\
\hline 1 & Days to $50 \%$ flowering & $-0.2872 * *$ & $0.2820 * *$ & 0.0825 & $0.3040 * *$ & 0.0510 & 0.0183 & 0.1311 \\
\hline 2 & Days to $50 \%$ boll bursting & -0.0324 & -0.0431 & 0.1473 & 0.2142 & 0.0331 & 0.1092 & -0.0838 \\
\hline 3 & Plant height $(\mathrm{cm})$ & -0.0373 & 0.1497 & 0.0223 & -0.0045 & -0.0662 & -0.092 & -0.0407 \\
\hline 4 & No. of sympodia per plant & -0.0592 & -0.1648 & -0.1085 & $-0.2740^{*}$ & -0.1036 & 0.1253 & 0.0567 \\
\hline 5 & No. of bolls per plant & $-0.2781^{*}$ & 0.1227 & 0.0021 & -0.0038 & -0.0358 & 0.1603 & 0.7381 \\
\hline 6 & Boll weight (g) & 0.1558 & 0.1884 & $-0.2330^{*}$ & $-0.2572 *$ & $-0.2878 * *$ & 0.0981 & 0.1568 \\
\hline 7 & Ginning percent $(\%)$ & -0.0367 & -0.0782 & $-0.2177^{*}$ & -0.2107 & -0.1592 & 0.1288 & 0.0119 \\
\hline 8 & Lint index (g) & $0.6023 * *$ & -0.1090 & -0.0530 & 0.0699 & 0.0164 & -0.0648 & -0.1406 \\
\hline 9 & Seed index $(g)$ & 1 & -0.0313 & -0.1082 & -0.1442 & -0.1745 & 0.1167 & -0.2006 \\
\hline 10 & Harvest index $(\mathrm{g})$ & & 1 & -0.0019 & -0.1077 & -0.0181 & -0.1393 & 0.1984 \\
\hline 11 & Upper half mean length (mm) & & & 1 & 0.1368 & $0.4143 * *$ & $-0.4806^{* *}$ & -0.0047 \\
\hline 12 & Uniformity ratio & & & & 1 & 0.1530 & 0.0580 & -0.1049 \\
\hline 13 & Fiber strength $(\mathrm{g} / \mathrm{tex})$ & & & & & 1 & $-0.3283 * *$ & -0.0776 \\
\hline 14 & Micronaire (ug/inch) & & & & & & 1 & 0.1880 \\
\hline 15 & Seed cotton yield per plant (g) & & & & & & & 1 \\
\hline
\end{tabular}

$*$ and $* *$ indicates significance at $5 \%$ and $1 \%$ level respectively 
Table.3 Path coefficient analysis for yield and yield contributing characters

\begin{tabular}{|c|c|c|c|c|c|c|c|c|c|}
\hline $\begin{array}{l}\text { Sr. } \\
\text { No. }\end{array}$ & Characters & $\begin{array}{l}\text { Days to } 50 \% \\
\text { flowering }\end{array}$ & $\begin{array}{l}\text { Days to } 50 \% \\
\text { Boll bursting }\end{array}$ & $\begin{array}{l}\text { Plant height } \\
\quad \text { (cm) }\end{array}$ & $\begin{array}{l}\text { Number of } \\
\text { sympodia per } \\
\text { plant }\end{array}$ & $\begin{array}{c}\text { Number of bolls } \\
\text { per plant }\end{array}$ & Boll weight (g) & $\begin{array}{l}\text { Ginning } \\
\text { percent }\end{array}$ & Lint index (g) \\
\hline & & 1 & 2 & 3 & 4 & 5 & 6 & 7 & 8 \\
\hline 1 & Days to $50 \%$ flowering & 0.2571 & 0.0433 & 0.0584 & 0.0194 & 0.0610 & -0.0287 & -0.1070 & -0.0680 \\
\hline 2 & Days to $50 \%$ boll bursting & 0.0095 & 0.0564 & 0.0155 & -0.0134 & -0.0003 & -0.0166 & -0.0300 & -0.0217 \\
\hline 3 & Plant height (cm) & 0.0059 & 0.0071 & 0.0259 & 0.0005 & -0.0006 & -0.0025 & -0.0132 & -0.0024 \\
\hline 4 & No. of sympodia per plant & 0.0055 & -0.0173 & 0.014 & 0.0732 & 0.0150 & 0.0130 & -0.0017 & -0.0041 \\
\hline 5 & No. of bolls per plant & 0.2315 & -0.0058 & -0.0228 & 0.1997 & 0.9765 & 0.2732 & -0.107 & -0.0981 \\
\hline 6 & Boll weight (g) & -0.0441 & -0.1159 & -0.0389 & 0.0703 & 0.1105 & 0.3950 & 0.1261 & 0.1507 \\
\hline 7 & Ginning Percent $(\%)$ & -0.0605 & -0.0773 & -0.0743 & -0.0033 & -0.0016 & 0.0464 & 0.1454 & 0.0180 \\
\hline 8 & Lint index (g) & 0.1309 & -0.1902 & 0.0465 & 0.0280 & 0.0497 & -0.1889 & -0.0612 & -0.4952 \\
\hline 9 & Seed index $(\mathrm{g})$ & -0.0206 & -0.0126 & -0.0026 & -0.0029 & -0.0190 & 0.0094 & -0.0030 & 0.0310 \\
\hline 10 & Harvest Index (g) & -0.1557 & 0.0011 & -0.0734 & 0.0314 & -0.0396 & -0.0894 & -0.0030 & 0.0230 \\
\hline 11 & Upper half mean length (mm) & -0.0621 & -0.0901 & -0.0224 & 0.0084 & -0.0134 & 0.2116 & 0.1366 & 0.0877 \\
\hline 12 & Uniformity ratio & -0.0621 & -0.0281 & -0.0023 & 0.0492 & -0.0049 & 0.0698 & 0.0364 & 0.0079 \\
\hline 13 & Fiber strength (g/tex) & 0.0061 & 0.0029 & -0.0128 & -0.0264 & -0.0068 & -0.0982 & -0.0399 & -0.0067 \\
\hline 14 & Micronaire (ug/inch) & -0.0184 & -0.0413 & 0.0687 & ก กั- & -0.1389 & -0.2314 & -0.1082 & 0.0990 \\
\hline \multirow[t]{2}{*}{15} & Seed cotton yield per plant $(\mathrm{g})$ & 0.2231 & -0.0874 & -0.0332 & 0.2250 & 0.9876 & 0.3626 & 0.0665 & -0.2789 \\
\hline & Partial $R^{2}$ & 0.0574 & -0.0049 & -0.0009 & 0.0165 & 0.9644 & 0.1432 & 0.0097 & -0.0271 \\
\hline
\end{tabular}


Table.3 Conti...

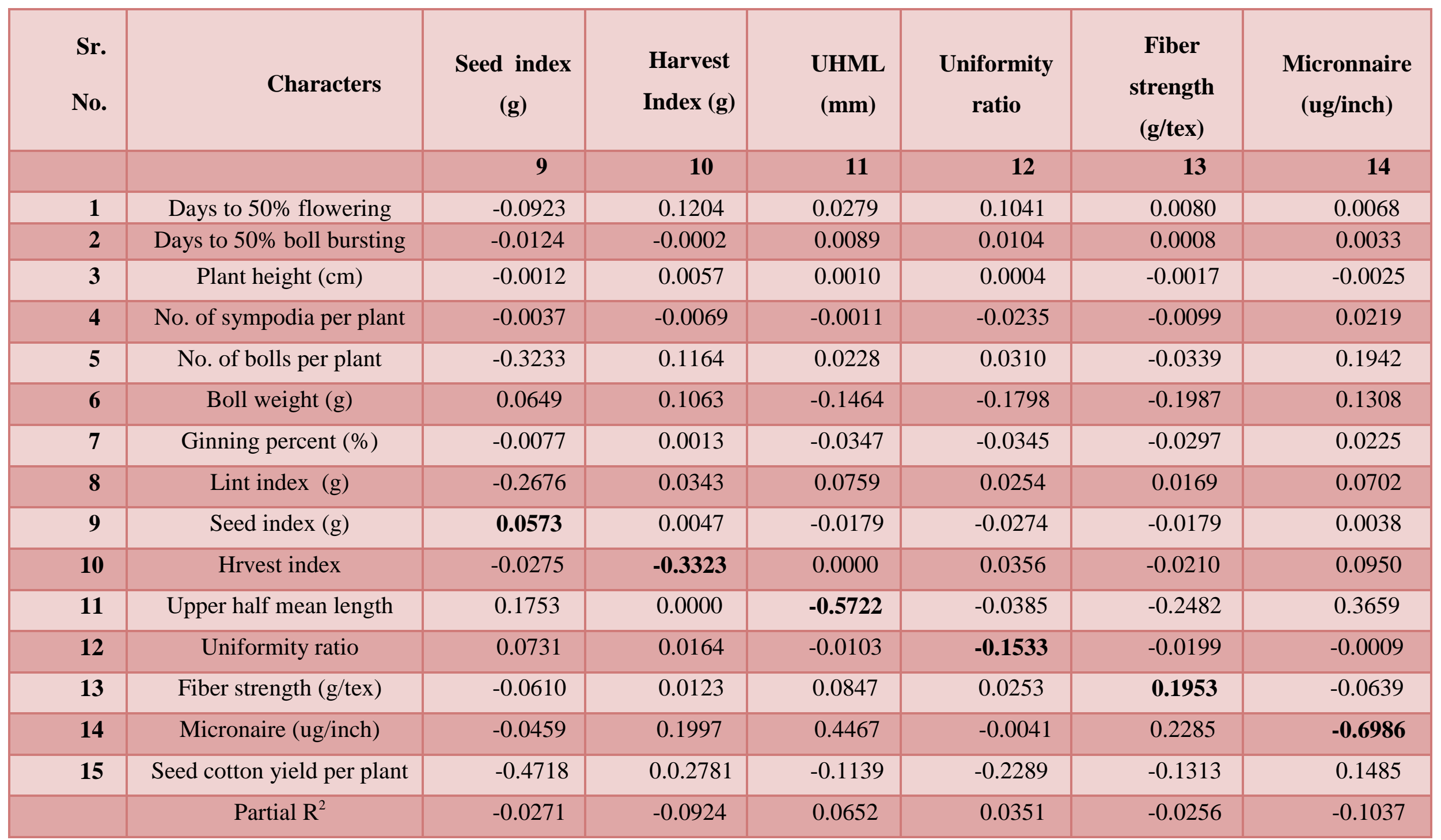


The character upper half mean length has negative direct effect $(-0.5722)$ on seed cotton yield and negative indirect effect via., fiber strength (-0.2482), number of bolls per plant $(-0.0134)$, plant height $(-0.0224)$, uniformity ratio (-0.0385), days to $50 \%$ flowering ($0.0621)$, days to $50 \%$ boll bursting (-0.0901). The character fiber strength has positive direct effect $(0.195$ on seed cotton yield and negative indirect effect via., plant height ($0.0128)$, number of sympodia per plant (0.0264), ginning percent (-0.0399), boll weight (-0.0982) and micronaire (-0.0639) was noticed. Positive indirect effect via., harvest index (0.0123), uniformity ratio (0.0253) and upper half mean length (0.0847) was observed.

The characters at both genotypic and phenotypic level showed that days to $50 \%$ flowering, number of bolls per plant, harvest index, ginning percent, fiber strength and uniformity ratio was significantly and positively correlated with seed cotton yield per plant. There was negative and non-significant correlation of plant height, seed index, lint index, upper half mean length, and uniformity ratio with seed cotton yield per plant.

Similar results were reported by Dahar et al., (2007), Mahentesh et al., (2010), Tulasi et al., (2012), Erande et al., (2014), Patil et al., (2014), Santoshkumar et al., (2014), Dahiphale et al., (2015), Reddy et al., (2015) and Gulhane and Wadikar (2017).

\section{References}

Bayyapu Reddy, V. Chenga Reddy, M. Lal Ahmed, T.C.M. Naidu and Srinivasarao, V. 2015. Correlation and path coefficient analysis in upland cotton (Gossypium hirsutum L.). Int. J. Pure App. Biosci. 3 (3): 70-80.

Dahar M.H., Z.A. Soomro and Tunio, M.A. 2007. Evaluation of cotton genotypes using correlation and path coefficient analysis. Life sciences international journal, Vol. 1, No.3, Page No. 224228.

Dahiphale K.D., J. D. Deshmukh, A.B. Jadhav and Bagade, A.B. 2015. Genetic variability, correlation and path coefficient analysis for yield and its attributing traits in cotton $(G$. hirsutum). IJTA Serials Publications, 33 (1).

Dewey, D.R. and Lu, K.H. 1959. A correlation and path coefficient analysis of components of crested wheat grass seed production. Agron. J., 51(9): 515518.

Erande C.S., Kalpande H.V., Deosarkar D.B., Chavan S.K., Patil V.S., Deshmukh J.D., Chinchane V.N., Anil Kumar, Utpal Dey and Puttawar M.R. 2014. Genetic variability, correlation and path analysis among different traits in desi cotton ( $G$. arboreum L.). African Journal of Agricultural Research, 9 (29), pp. 2278-2286.

Farooq J., M. Anwar, M. Riaz, A. Farooq, A. Mahmood, M. T. H. Shahid, M. Rafiq S. and F. Ilahi. 2014. Correlation and path coefficient analysis of earliness, fiber quality and yield contributing traits in cotton (Gossypium hirsutum L.). Journal of Animal \& Plant Sciences, 24 (3): pp.781-790.

Gulhane Ashish and Wadikar, M.S. 2017. Genotypic path coefficient analysis of cotton derived through introgression. Int. J. Curr. Microbiol. App. Sci, 6 (2): 49-55.

Iqbal Muhammad, Khezir Hayat Bhatti and Sohail R. 2006. Correlation and path coefficient analysis for earliness and yield traits in cotton (G. hirsutum L.). Asian Journal of Plant Sciences, 10:341.344.

Johnson, H.W., Robinson, H.F. and Comstock, R.E. 1955. Genotypic and 
phenotypic correlations in soybean and their implications in selection. Agron. J., 47: 477-483.

Leela Pratap, K., Chenga Reddy, V., Rama Kumar, P. V. and Srinivasa Rao, V. 2007. Correlation and path coefficient analyses for yield and yield component traits in cotton (Gossypium hirsutum L.). Andhra Agric. J., 54: 31-35.

Mahantesh, Lal Ahamed, M., Panduranga Rao, C. and Samba Murthy, J. S. V. 2010. Character association and path coefficient analysis in upland cotton (Gossypium hirsutum L.). Andhra Agric. J., 57: 230-233.

Mahdi A.H.A. 2014. Correlation and path coefficient analysis of lint yield and its components in Egyptian cotton. Bulletin of Faculty of Agriculture, Cairo University 65:398-404.

Patil Malagouda, B.M. Khadi, Kumari Basamma and Katageri, I.S. 2014. Genetic variability and correlation analysis for fibre quality traits in diploid cotton (Gossypium spp). American-Eurasian J. Agric. \& Environ. Sci., 14 (5): 392-395.

Rao M.J. and Gopinath M. (2013). Studied 60 cotton genotypes for yield and fiber quality traits in red chalk soil. Electronic J. Plant breeding, 4(1): 1093-1096.

Salahuddin Shazia, Saifullah Abro, A. Rehman and Khalid Iqbal. 2010.
Correlation analysis of seed cotton yield with some quantitative traits in upland cotton (Gossypium hirsutum L.). Pak. J. Bot., 42 (6): 3799-3805.

Santoshkumar Pujer, S.S. Siwach, Jagadeesh Deshmukh, R.S. Sangwan and Sangwan, O. 2014. Genetic variability, correlation and path analysis in upland cotton (Gossypium hirsutum L.). Electronic Journal of Plant Breeding, 5 (2): 284-289.

Shakeel Ahmad, Sajid Fiaz, Aamir Riaz, Ikram Bashir, Aqib Zeb. 2016. Correlation analysis of morphological and fiber quality traits in upland cotton (G.hirsutum L.). International Journal of Biosciences., 9 (4): 200-208.

Tamilselvam G., R. Rajendran and Anbarasan, K. 2013. Association and path analysis in cotton (Gossypium hirsutum L.). International Journal of Research in Plant Science; 3 (2): 3638.

Tulasi J., Lal Ahamed M., J.S.V. Samba Murthy and Ashoka Rani, Y. 2012. Correlation and path analysis in American cotton. Electronic Journal of Plant Breeding, 3 (4): 1005-1008.

Yaqoob Muhammad, Sajid Fiaz and Babar Ijaz. 2016. Correlation analysis for yield and fiber quality traits in upland cotton. Communications in Plant Sciences, 6 (34): 55-60.

\section{How to cite this article:}

Mankar, A. D., D. B. Deosarkar and Chinchane, V. N. 2021. Correlation and Path Coefficient Analysis for Seed Cotton Yield and its Components in Desi Cotton (Gossypium arboreum L.). Int.J.Curr.Microbiol.App.Sci. 10(02): 2126-2136. doi: https://doi.org/10.20546/ijcmas.2021.1002.253 